\title{
DINAMIKA KEPRIBADIAN TOKOH DALAM NOVEL HARAPAN DI ATAS SAJADAH KARYA MAWAR MALAKA
}

\author{
Rahmatia Nasaru' ${ }^{1}$, Moh. Karmin Baruadi ${ }^{2}$, Ellyana Hinta ${ }^{3}$
}

\section{Info Artikel \\ Sejarah Artikel: \\ Diterima Februari 2021 \\ Disetujui Maret 2021 \\ Dipublikasikan Mei 2021}

\begin{abstract}
Penelitian ini bertujuan untuk mendeskripsikan dinamika kepribadian tokoh dalam novel Harapan di Atas Sajadah karya Mawar Malka. Teori yang digunakan adalah psikologi Jung yaitu teori tentang pentingnya kesadaran dan ketidaksadaran membentuk pribadi yang utuh berkaitan dengan pengalaman dan hubungan dengan Sang Pencipta. Metode penelitian menggunakan metode deskriptif kualitatif. Data penelitian berupa kutipan-kutipan melalui dialog antar tokoh maupun cerita yang menggambarkan dinamika kepribadian dari segi prinsip-prinsip interaksi, fungsi, dan tujuan penggunaan energi psikis. Hasil penelitian dan pembahasan menunjukkan bahwa (1) dinamika kepribadian dari segi prinsipprinsip interaksi terdiri atas prinsip oposisi, kompensasi, dan penggabungan. Prinsip ini menjadi dasar terjadinya dinamika kepribadian yang awalnya memiliki kepribadian buruk menjadi lebih baik, (2) dinamika kepribadian dari segi fungsi penggunaan energi psikis yakni adanya kekuatan semangat, keingingan, dan kemauan, (3) dinamika kepribadian dari segi tujuan penggunaan energi psikis terdiri atas progresi dan regresi. Progresi kepribadian tokoh menampilkan dua tipe kepribadian yakni sikap ekstrovert (terbuka) dan sikap introvert (tertutup). Dengan demikian, dinamika kepribadian tokoh menunjukkan perubahan yang signifikan. Perubahan yang berhubungan dengan persoalan sosial dan hubungannya dengan Sang Maha Pencipta menuju ke arah lebih baik.
\end{abstract}

Kata kunci: dinamika kepribadian, tokoh, novel, psikologi Jung

\footnotetext{
Alamat Korespondensi:

Jurusan Bahasa dan Sastra Indonesia, Fakultas Sastra dan Budaya, Universitas Negeri Gorontalo Email: nasarurahmatia@gmail.com; karminbaruadi@ung.ac.id; ellyanahinta@ung.ac.id
} 


\section{ABSTRACT}

This study aims to describe the personality dynamics of the characters in the novel Harapan Di Atas Sajadah by Mawar Malka. The theory used is Jungian psychology, namely the theory of the importance of consciousness and the unconscious to form a complete person in relation to experiences and relationships with the Creator. The research method used a qualitative descriptive method. The research data is in the form of quotes through dialogue between characters and stories that describe the dynamics of personality in terms of the principles of interaction, function, and purpose of using psychic energy. The results of the research and discussion show that (1) the dynamics of personality in terms of the principles of interaction consist of the principles of opposition, compensation, and merger. This principle becomes the basis for the dynamics of personality that initially has a bad personality to become better, (2) personality dynamics in terms of the function of using psychic energy, namely the strength of enthusiasm, desire, and will, (3) personality dynamics in terms of the purpose of using psychic energy consisting of progressions and regressions. The personal progression of a character displays two types of personality, namely an extroverted attitude (open) and an introverted attitude (closed). Thus, the dynamics of the character's personality show significant changes. Changes related to social problems and their relationship with the Creator for the better.

Keywords: personality dynamics, characters, novels, Jungian psychology 


\section{PENDAHULUAN}

Persoalan hidup akan selalu hadir menemani setiap langkah dalam memperjuangkan kehidupan dunia menuju akhirat. Berbagai persoalan mulai dari masalah keluarga, sosial, sampai hubungan dengan Sang Pencipta. Namun, kenyataannya seseorang selalu menunjukkan sikap kurang baik dan tidak menerima bahwa setiap persoalan sudah menjadi ketetapan-Nya. Hal ini mempengaruhi kepribadian dalam penyesuaian terhadap persoalan yang dihadapi. Terlebih ketika penyesuaiannya kurang dalam hubungannya dengan Sang Pencipta, sehingga hubungan sosialnya juga tidak berjalan dengan baik.

Sikap dalam memandang persoalan hidup tersebut berkaitan dengan kepribadian seseorang. Kepribadian menurut Santrock (dalam Sembiring. dkk., 2018: 160) yaitu (1) openness, yaitu imajinatif atau praktis, variatif atau mengacu pada rutinitas, independen atau mudah beradaptasi. (2) Conscientiousness, yaitu rapi atau tidak rapi, perhatian atau ceroboh, disiplin, atau impulsif. (3) Extraversion, yaitu terbuka secara sisoal atau penyendiri, periang atau pemurung, welas asih atau tidak peduli. (4) Agreeableness, yaitu lembut atau kasar, mudah percaya atau mudah curiga, kooperatif atau nonkooperatif. (5) Neuroticism, yaitu tenang atau cemas, aman atau tidak aman, merasa puas atau tidak puas. Kepribadian tersebut akan mengalami dinamika terkait dengan masalah dan penyesuaian diri terhadap lingkungan.

Novel Harapan di Atas Sajadah (selanjutnya disingkat HAS) menyajikan tokoh-tokoh dengan beragam karakter dan kisah perspektif yang berbeda. Terutama dalam menjalankan peran sebagai seseorang yang hidup di lingkungan bermasyarakat dengan selalu menghadirkan Sang Pencipta di dalamnya. Dengan kata lain, tokoh-tokoh tersebut memiliki kepribadian yang berbeda dalam menjalankan peran mereka yang berkaitan dengan ketetapan Sang Pencipta.

Kisah yang ditorehkan Mawar di dalam novel ini adalah ketakwaan dan ikhtiar dalam menjalani kehidupan yang penuh dengan cobaan. Para tokoh yang dihadirkan oleh penulis merupakan tokoh yang dengan kesabarannya menghadapi masalah, baik dari keluarga hingga masyarakat di lingkungan tempat tinggalnya. 
Hal yang menarik adalah ketika tokoh yang melakoni seorang istri mampu menghadapi suami yang tidak pernah mencintainya. Hanya ada pertentangan, tidak ada kasih sayang dan cinta menyelimuti rumah tangga tersebut. Namun, seorang istri tetap menjalankan kewajibannya demi ketaatannya sesuai alquran dan sunah. Di sisi lain, harus menanggung cacian dan makian dari masyarakat yang membenci penampilannya sesuai syariat Islam. Kepribadian yang dimiliki oleh tokoh tersebut, mempengaruhi tokoh lainnya. Tokoh lain yang awalnya membenci sunah dan tidak menjalankan ketaatannya kepada Sang Pencipta, kini berubah menjadi lebih baik. Perubahan yang terjadi dari tokoh, tidak lain sebagai bentuk interaksi yang terjadi, karena terdapat beberapa aspek yang mempengaruhi. Oleh karena itu, hal tersebut menimbulkan adanya dinamika kepribadian yang terjadi pada setiap tokoh.

Dinamika kepribadian merupakan gerak perubahan yang terjadi pada diri individu untuk mencapai tujuan. Hal itu terjadi karena dipengaruhi oleh peristiwa-peristiwa yang terjadi pada masa kini, namun berawal dari peristiwa sebelumnya, sehingga membentuk pada kepribadian yang utuh. Peristiwa-peristiwa tersebut misalnya berhubungan dengan persoalan sosial dan religi. Persoalan sosial biasanya berkaitan dengan hubungan antarkeluarga dan masyarakat, pertengkaran suami-istri, kesalahpahaman dalam rumah tangga, penipuan, ketidakpercayaan, permusuhan, rasa iri dan dendam, serta masalah sosial lainya. Persoalan religi berkaitan dengan ketidakpercayaan atas keagungan Sang Pencipta, tidak menerima takdir, tidak bersyukur, dan tidak menjalankan sunah-sunah Rasulullah sallallahu alaihi wa sallam. Kepribadian tokoh tersebut menunjukkan jauh dari sifat religius. Namun, dengan berbagai cobaan hidup yang menimpa, membuat adanya dinamika kepribadian, hingga mencapai tingkat keimanan seorang hamba yang dekat dengan Sang Pencipta.

Pengkajian mengenai dinamika kepribadian dapat dianalisis menggunakan teori psikologi Jung. Psikologi Jung mengacu pada tiga teori yakni struktur, dinamika, dan perkembangan. Namun, dalam peneliian ini menggunakan teori yang kedua, yakni dinamika kepribadian. Dinamika kepribadian terhadap individu mengalami perubahan, karena terdapat aspek-aspek yang mempengaruhinya. Aspek-aspek tersebut berkaitan dengan sikap jiwa individu ketika menghadapi setiap permasalahan dalam hidupnya. Sikap jiwa tersebut 
sebagai perwujudan dari tingkah laku manusia yang terbentuk karena dipicu oleh masa lalu, tujuan, dan aspirasi masa depan. Hal itu tidak terlepas dari adanya energi psikis yang digunakan. Energi psikis akan nampak pada kekuatan semangat, kemauan, dan keinginan dari individu. Selain itu, energi psikis tersebut akan memberikan pengaruh bagi pengembangan kehidupan, aktivitas kultural, dan spritual. Dengan demikian, psikologi Jung dapat mengungkap bahwa segala permasalahan hidup, aspirasi masa depan, masa lalu, dan tujuan menyebabkan adanya dinamika kepribadian dari sisi prinsip-prinsip interaksi, fungsi, dan penggunaan energi psikis. Selain itu, dapat mengungkap bahwa ketetapan Sang Pencipta yang diberikan kepada hamba-Nya sebagai rasa cinta, agar lebih dekat dan mengenal-Nya.

Berdasarkan pemaparan di atas, penelitian psikologi Jung ini difokuskan pada tiga aspek sebagai berikut. pertama, dinamika kepribadian tokoh dari segi prinsip-prinsip interaksi; kedua, dinamika kepribadian tokoh dari segi fungsi penggunaan energi psikis; dan ketiga, dinamika kepribadian tokoh dari segi tujuan penggunaan energi psikis.

\section{METODE PENELITIAN}

Data-data penelitian ini dikualitatifkan berdasarkan dinamika kepribadian tokoh dalam novel Harapan di Atas Sajadah karya Mawar Malka. Oleh karena jenis penelitian ini adalah deskriptif, maka metode yang digunakan adalah deskriptif kualitatif. Data penelitian diuraikan dari kutipan-kutipan melalui dialog antar tokoh maupun cerita yang menggambarkan dinamika kepribadian dari segi prinsip-prinsip interaksi, fungsi, dan tujuan penggunaan energi psikis. Data-data tersebut diambil dari teks yang terdapat di dalam novel Harapan di Atas Sajadah karya Mawar Malka cetakan pertama yang diterbitkan oleh Wahyu Qolbu dan berjumlah 542 halaman. Data diperoleh dari teknik pembacaan dan pencatatan terhadap kutipan teks yang terkait dengan dinamika kepribadian tokoh dari segi prinsipprinsip interaksi, fungsi, dan tujuan penggunaan energi psikis. Data dianalisis dengan tahapan klasifikasi, analisis, deskripsi, dan interpretasi terkait dengan dinamika kepribadian tokoh dari segi prinsip-prinsip interaksi, fungsi, dan tujuan penggunaan energi psikis. 


\section{HASIL PENELITIAN}

Mawar Malka mengangkat tokoh-tokoh dalam novel Harapan di Atas Sajadah (HAS) dengan adanya perubahan terhadap kepribadian. Perubahan tersebut tidak terlepas dari adanya aspek-aspek yang mempengaruhi. Aspek-aspek tersebut berupa prinsip-prinsip interaksi, fungsi, dan tujuan penggunaan energi psikis. Ketiga aspek ini kemudian dibahas secara teoretis menggunakan kerangka berpikir psikologi Jung, sehingga dinamika kepribadian yang ditunjukkan oleh setiap tokoh di dalam novel HAS menjadi representasi dan dinamika kepribadian yang terjadi sesuai dengan psikologi Jung. Berikut uraiannya.

\section{Dinamika Kepribadian Tokoh ditinjau dari Segi Prinsip-prinsip Interaksi}

Beberapa hasil penelitian mengenai dinamika kepribadian tokoh dari segi prinsipprinsip interaksi: pertama, prinsip oposisi berinteraksi dengan tiga cara yakni saling bertentangan, saling mendukung, dan bergabung menjadi kesatuan; kedua, prinsip kompensasi; dan ketiga prinsip penggabungan.

\section{Prinsip Oposisi}

Prinsip oposisi merupakan prinsip yang pertama dalam prinsip-prinsip interaksi. Prinsip ini berisi konflik yang terjadi, ketika adanya hubungan dengan pihak lain. Konflik tersebut terbagi menjadi tiga tingkatan yakni saling bertentangan, saling mendukung, dan bergabung menjadi kesatuan. Berikut hasil paparannya.

1) Saling Bertentangan

Pertentangan merupakan tingkatan yang pertama dalam prinsip oposisi. Pertentangan merupakan pertikaian yang terjadi kepada orang yang berselisih paham. Saling bertentangan yang terjadi dipresentasikan oleh tokoh Pras bersama kedua orang tuanya yang menginginkannya menikah, namun Pras menolaknya.

"Papa sama mama udah dapet calon istri buat kamu, Nak," ujar Devika.

Pras berdiri. "Apa-apaan sih, Ma, Pa? Aku belum setuju buat nikah!" Pekik Pras.

"Ini keputusan papa sama mama dan bukan permintaan," tukas Andi mencoba tenang. "Pak, aku nggak kenal dia," bantah Pras (Malka, 2018: 18-19). 
Sikap Pras yang menolak permintaan kedua orang tuanya untuk menikah. Hal tersebut memicu adanya pertentangan dalam keluarganya. Dengan demikian, pertentangan yang terjadi antara Pras dan kedua orang tuanya, termasuk dalam dinamika kepribadian Jung, yaitu suatu bentuk akibat dari konflik yang sering terjadi. Sikap keras Pras atas penolakan yang ia lakukan terhadap orang tuanya menunjukkan kepribadiannya yang kasar, pembangkang, dan tidak bersyukur atas nikmat yang Allah taala berikan kepadanya.

\section{2) Saling Mendukung}

Saling mendukung merupakan tingkatan yang kedua dari prinsip oposisi setelah saling bertentangan. Saling bertentangan dari kedua belah pihak akan mencapai saling mendukung ketika permasalahan atau konflik yang diperselisihkan sudah jelas.Saling mendukung dipresentasikan oleh kedua belah pihak yang awalnya bertentangan, yaitu Pras dan kedua orang tuanya.

Andi memejamkan mata mencoba menenangkan dirinya lagi. "Sekarang pilihan kamu cuma dua, Pras. Menikah atau kehilangan warisan?" tanya Andi dengan nada tegas. Pras mengusap rahangnya. Kali ini ia benar-benar frustasi. Ia merasa tersudut dengan pilihan yang diberikan sang papa. "Oke, oke, aku mau menikah!" Pekiknya sambil berdiri dan berlalu dari kedua orang tuanya (Malka, 2018: 21).

Pras mendukung keputusan kedua orang tuanya yang menginginkannya menikah. Dengan demikian, sikap Pras yang mengikuti permintaan kedua orang tuanya menunjukkan adanya sikap yang patuh terhadap keputusan yang sudah disepakati.

3) Bergabung Menjadi Kesatuan

Bergabung menjadi kesatuan merupakan tingkatan terakhir dalam prinsip oposisi setelah melewati berbagai pertentangan hingga sampai pada saling mendukung.Bergabung menjadi kesatuan ini dipresentasikan oleh Pras saat mengikuti permintaan kedua orang tuanya.

Pras mengucapkan qabulnya dengan lantang tanpa beban. "Saya terima nikah dan kawinnya Adara Prasmaya binti Riyadi Pramana dengan mas kawin yang telah disebutkan, tunai!" (Malka, 2018: 26).

Ijab kabul yang diucapkan oleh Pras, sebagai tanda pernikahan telah dilaksanakan dan 
mencapai puncak kebahagiaan yang awalnya Pras menolak permintaan kedua orang tuanya. Dengan demikian, pernikahan yang dilakukan Pras sebagai bentuk kepatuhannya terhadap keputusan kedua orang tuanya.

\section{Prinsip Kompensasi}

Prinsip kompensasi merupakan tindakan individu untuk mencegah agar kepribadian tidak menjadi gangguan pada bagian saraf. Prinsip kompensasi lainnya dipresentasikan oleh tokoh Adara. Sikap Adara yang tidak kuat dalam menghadapi setiap masalah dalam kehidupannya, membuat ia berputus asa dari rahmat Allah taala.

"Nak Dara, kenapa pulang selarut ini? Ibu khawatir." Haniyah memegangi tangan Adara yang tengah mabuk berat.

"Lepasin!" teriaknya mengempaskan tangan Haniyah.

"Dara, jangan bengini, Nak. Papa sama mama Dara pasti sedih liat Dara seperti ini." Haniyah menangis melihat anak angkatnya kelimpungan karena pengaruh alkohol (Malka, 2018: 165).

Sikap frustasi Adara ditunjukkan melalui kondisinya setelah kepergian kedua orang tuanya, sehingga sikap tak sadar mengambil alih. Sikap tak sadar tersebut ditunjukkan dengan kepulangannya dengan kondisi mabuk, sehingga kata-kata yang keluar dari mulutnya mencela dan tidak menerima ketetapan Allah taala. Dengan demikian, sikap tak sadar Adara menunjukkan kepribadian Adara yang buruk melalui caranya yang tidak ikhlas menghadapi setiap masalah, berprasangka buruk kepada Allah taala, dan menzalimi diri sendiri.

\section{Prinsip Penggabungan}

Prinsip penggabungan sebagai prinsip untuk menyatukan berbagai pertentangan.Prinsip penggabungan dipresentasikan oleh tokoh Adara. Adara dalam menghadapi setiap pertentangan dari Pras suaminya, selalu berusaha untuk menghindari pertentangan tersebut.

Memasuki kamar, ia melihat lemari di kamar berantakan dan pakaian busana pernikahan tergeletak berserakan di lantai. Ia kembali memeriksa sekeliling kosong. Adara terdiam. Mungkin dia sudah pergi, batinnya. Adara meraih sajadah lalu menghamparkannya. Ia mulai mendirikan salat hajat. Selesai salat hajat, ia sujud lagi dan membaca doa Nabi Yunus ketika di dalam perut ikan paus (Malka, 2018: 33-34). 
Perlakuan Pras yang meninggalkan Adara tanpa pamit di malam pertama pernikahan mereka, membuat Adara sakit hati. Namun ia mencoba bersabar dan memilih untuk tidak mempermasalahkannya. Hal itu termasuk dalam dinamika kepribadian Jung, yaitu suatu bentuk untuk menyatukan pertentangan yang ada.

\section{Dinamika Kepribadian Tokoh ditinjau dari Segi Fungsi Penggunaan Energi Psikis}

Dinamika kepribadian tokoh ditinjau dari segi fungsi penggunaan energi psikis dapat dilihat dari: (1) kekuatan semangat; dan (2) kemauan dan keinginan (Alwisol, 2011: 50). Secara spesifik, masing-masing dari kedua fungsi ini diwujudkan dalam tingkah laku yang ditemukan dalam novel HAS.

\section{Kekuatan Semangat}

Kekuatan semangat merupakan motivasi yang timbul dari diri seseorang untuk mencapai tujuan tertentu.Kekuatan semangat ini dipresentasikan oleh Adara, istri dari Pras.Kekuatan semangat tersebut terpancar dari sikap Adara yang selalu bersabar dan bersyukur dalam beribadah kepada Allah taala.

Jam menunjukkan pukul setengah tiga dini hari. Adara menghamparkan sajadah untuk salat Tahajud pada sepertiga malam. Selesai salat, ia lamakan sujudnya, larut dalam doa. Sujudku bagai pelukan-Mu ya Allah. Apalah hamba, hanya manusia lemah. Harapan hamba hanya di sini. Di atas sajadah ini. Ya Allah... Berdoa pada-Mu. Mengikhlaskan semua yang pernah terjadi. Terima kasih atas semua kepahitan yang mengantarkan hamba mengenal-Mu. Ini surga hamba. Surga saat dekat dengan-Mu (Malka, 2018: 154-155).

Adara memiliki kekuatan semangat untuk melanjutkan kehidupan atas segala masalah menimpanya. Masalah tersebut menjadikannya pribadi yang lebih taat, bertakwa, dan ikhlas.

Kekuatan semangat lainnya dipresentasikan oleh tokoh Pras. Perusahaan yang dimiliki Pras kini terancam bangkrut, sehingga adanya kekuatan semangat yang memotivasi untuk dapat memulihkan perusahaannya tersebut.

Pras melangkahkan kaki ke luar rumah orang tuanya. Tekadnya sudah kuat, apa pun dan bagaimanapun caranya, ia harus bisa memulihkan keadaan perusahaan (Malka, 2018: 362). 
Pras memiliki kekuatan semangat yang besar untuk memulihkan perusahaan yang kini terancam bangkrut. Hal itu terlihat ketika ia memiliki tekad yang kuat dan berjanji untuk mencari cara agar perusahaannya tidak bangkrut.

2. Kemauan dan Keinginan

Kemauan dan keinginan merupakan suatu dorongan untuk mencapai tujuan. Kemauan merupakan dorongan melalui usaha nyata atau ikhtiar yang dilakukan, sedangkan keinginan merupakan dorongan berupa harapan dalam bentuk doa. Kemauan dan keinginan dipresentasikan oleh tokoh Adara yang memiliki potensi besar dalam mencapai kabahagiaan melalui harapan di setiap usaha dan doanya.

"Ya Allah, ya muqalibal quluub, tsabbits qalbi 'alaa diinika. Wahai Dzat Yang Maha membolak-balikkan hati, tetapkanlah hatiku pada agama-Mu, jadikan pernikahan ini abadi. Cinta ini abadi. Cinta dari dunia menuju akhirat dan keridhaan-Mu." (Malka, 2018: 29).

Adara memiliki keinginan untuk diberikan hati yang selalu istikamah di atas agama Allah taala. Usaha yang dilakukan Adara untuk menjadikan pernikahannya diridai-Nya dengan menunjukkan sikap baik, sabar menghadapi suaminya yang kasar, dan selalu berdoa untuk diberikan petunjuk. Oleh karena itu, segala bentuk kemauan dan keinginan dari diri Adara merupakan bagian dari fungsi penggunaan energi psikis.

\section{Dinamika Kepribadian Tokoh ditinjau dari Segi Tujuan Penggunaan Energi Psikis}

Dinamika kepribadian tokoh yang ditinjau dari segi tujuan penggunaan energi psikis diwujudkan melalui sikap ekstrovert (terbuka) dan sikap introvert (tertutup), serta regresi yang berupa ingatan masa lalu.

\section{Progresi}

Progresi merupakan gerak maju yang mempengaruhi adanya dinamika kepribadian. Progresi sebagai gerak maju untuk mewujudkan tujuan pengggunaan energi psikis diraih melalui sikap ekstrovert (terbuka) dan sikap introvert (tertutup).

1) Sikap Ekstrovert (Terbuka) 
Sikap ekstrovert (terbuka) tokoh ditunjukkan dengan perilaku dalam kaitannya dengan proses adaptasi dunia luar. Berikut beberapa sikap ekstrovert (terbuka) yang ditemukan dalam penelitian ini.

\section{(1)Lancar dalam pergaulan}

Lancar dalam pergaulan mengaitkan hubungan dalam bersikap antara individu terhadap masyarakat disekitarnya. Lancar dalam pergaulan dipresentasikan oleh tokoh Adara. Hal itu diperlihatkan dalam bentuk bertutur kata, akhlak yang baik, dan perilaku menyikapi sesuatu.

Devika tersenyum. "Kamu memang manis, sayang. Semanis sikap kamu, semanis akhlak dan tutur kamu. Mama berdoa, semoga Allah kasih jalan buat kalian berdua jadi keluarga yang sempurna, dan diridhoi Allah."

"Aamiin, ya Rabb. Makasih doanya ya, Ma." (Mallka, 2018: 47).

Data di atas mengindikasikan sikap Adara yang mampu membuat ibu mertuanya memiliki rasa kasih sayang terhadapnya. Hal itu tidak terlepas dari sikap Adara yang selalu menunjukkan sikap kepedulian terhadap ibu mertuanya.

Lancar dalam pergaulan lainnya dipresentasikan oleh tokoh Pras. Sikap Pras awalnya dingin dan angkuh, kini berubah menjadi ramah terhadap orang-orang disekitarnya, menunjukkan pergaulan berjalan dengan lancar.

"Sayangku udah makan?" tanya Pras sambil mengusap kepala Adara dengan lembut (Malka, 2018: 297).

Sikap Pras yang ramah terhadap istrinya, Adara terlihat dari cara ia memanggil dengan panggilan baik dan menanyakan kondisinya. Hal itu menunjukkan adanya pergaulan yang lancar dalam kehidupan rumah tangga mereka.

(2) Komunikasi sosialnya baik dan bersifat ramah tamah

Komunikasi merupakan pembicaraan yang dilakukan oleh dua orang atau lebih dalam menyampaikan pesan untuk dipahami. Penyampaian pesan dipresentasikan oleh tokoh Adara.

"Ini semua karena penampilan saya, Pak. Saya bisa meminta maaf. Tapi maaf, saya tak berhak meminta maaf karena cadar dan penampilan saya ini sudah jadi bagian hidup 
saya. Warga di sini bisa menilai saya apa saja, tapi saya tegaskan saya bukan teroris. Ajaran yang saya anut tidak pernah mengajarkan membunuh jiwa yang tidak bersalah. Bapak tenang saja, saya bukan teroris. Kami keluarga yang bersih dari itu," tagas Adara.

Pak Rahmat mengangguk puas. Ia tersenyum bangga dengan sikap Adara yang pandai menyakinkan dirinya (Malka, 2018: 71-72).

Sikap Adara yang berkomunikasi dengan baik bersama Pak RT (Rukun Tetangga). Sikap Adara dalam penyampaiannya membuat Pak RT puas dan yakin bahwa Adara dari keluarga yang baik-baik dan kabar tersebut tidak benar adanya.

Komunikasi yang baik lainnya dipresentasikan oleh tokoh Pras kepada ibu mertua dan istrinya. Komunikasi tersebut berjalan dengan lancar, karena disampaikan dengan penyampaian yang ramah dan menunjukkan sikap hormat terhadap orang lain.

Sementara Pras mendekat dan menyalaminya. "Maaf Bu, saya telat datangnya karena masih sibuk kerja," ujarnya ramah pada Haniyah (Malka, 2018: 156).

Keramahan Pras terhadap ibu mertuanya terlihat dari ucapannya yang sopan menunjukkan adanya pribadi lemah lembut, patuh, dan menghargai orang tua.

\section{(3) Berpembawaan riang gembira}

Berpembawaan riang gembira merupakan bentuk suasana hati yang merasa puas dan bahagia. Berpembawaan riang gembira dipresentasikan oleh tokoh Adara dalam menjalani setiap perannya.

Adara hanya tersenyum geli. Bagaimana tidak, ia tahu Pras sangat menyukai masakan yang ia buat. Ada rasa puas dalam hatinya (Malka, 2018: 85).

Sikap Adara yang bahagia menjalani perannya dan ikhlas menerima ketetapan dari Allah taala, menunjukkan bahwa dirinya berpembawaan riang gembira.

Berpembawaan riang gembira lainnya dipresentasikan oleh tokoh Pras dalam menjalani setiap perannya.

Pras mengangguk dengan senyum manisnya pada Adara. Ia semakin bersyukur mempunyai istri seperti Adara, yang selalu mengingatkannya untuk selalu dekat dengan Sang Pencipta (Malka, 2018: 282).

Pras merasa gembira memiliki istri salihah seperti Adara.Oleh karenanya, kebahagiaan 
yang tengah dirasakan Pras merupakan kenikmatan dari Allah taala berikan kepada setiap hamba-Nya yang selalu bersyukur.

(4) Optimis dan tidak putus asa dalam menghadapi konflik, serta bersikap tenang.

Sikap tenang akan memicu pihak lain untuk tetap optimis dan tidak putus asa, ketika terjadi konflik. Sikap tenang dalam menghadapi konflik dipresentasikan oleh tokoh Adara.

"Ngapain lo?"

"Buka sepatu Mas."

"Gue nggak butuh bantuan lo!" bentak Pras.

Adara tak menyahut dan tetap melepaskan sepatu dan kaos kaki Pras.

"Mas sebaiknya cepat mandi biar segar. Aku udah siapin makan malam buat Mas." (Malka, 2018: 67).

Sikap tenangnya Adara terlihat saat dirinya masih tetap melayani kebutuhan Pras, walaupun mendapat penolakan dan bentakan yang keras. Sikap Adara tersebut menunjukkan adanya sifat optimis dan tidak mudah putus asa dalam menghadapi konflik, serta bersikap tenang.

Sikap tenang dalam menghadapi konflik lainnya dipresentasikan oleh tokoh Pras ketika telah mengalami perubahan dari sisi akhlak.

"Lalu kenapa satu bulan ini tidak ada laba yang masuk ke perusahaan kami, sedangkan Bapak sudah menikmatinya?" tanya Pras mencoba tenang walaupun amarah di dadanya bergemuruh (Malka, 2018: 334).

Sikap Pras yang tidak meluapkan emosinya secara spontan, menunjukkan adanya sikap tenangnya dalam menghadapi masalah tersebut.

(5) Memiliki keuletan dalam berpikir

Berpikir menjadi salah satu cara untuk melakukan sesuatu dengan mempertimbangkan dampak yang akan terjadi.Keuletan dalam berpikir dipresentasikan oleh tokoh Adara dalam menghadapi berbagai masalah yang timbul.

"Maafkan aku, Mas. Aku pamit pergi. Semoga kau lekas mendapatkan pengganti seorang wanita suci yang baik dan tak mempunyai aib sepertiku. Adara Prasmaya." (Malka, 2018: 429).

Sikap Adara yang mengambil tindakan untuk pergi meninggalkan Pras. Oleh 
karenanya, ia berpikir dan pergi menjauh untuk mencari solusi dari akar permasalahan yang terjadi.

Keuletan dalam berpikir lainnya dipresentasikan oleh tokoh Pras dalam membuat rencana bersama investor lain.

Kami berencana akan membangun apartemen, restoran, dan berbagai wahana lainnya di hamparan hijau luas di depan pegunungan itu. Sementara pantai biarlah menjadi objek wisata alami (Malka, 2018: 321).

Ide cemerlang Pras menunjukkan bahwa ia memiliki keuletan dalam berpikir dalam merencanakan sesuatu agar berjalan sesuai dengan rencana.

\section{2) Sikap Introvert (Tertutup)}

Sikap introvert (tertutup) tokoh ditunjukkan dengan perilaku dalam kaitannya dengan proses adaptasi dunia luar. Proses adaptasi tersebut bersifat tertutup, artinya penyesuaian dengan lingkungan kurang baik dan mengalami berbagai hambatan. Berikut beberapa sikap introvert(tertutup) yang ditemukan dalam penelitian ini.

(1) Jiwanya tertutup

Jiwa tertutup merupakan kehidupan batin manusia melalui perasaan dan pikiran lebih menutup diri dan bersifat tertutup terhadap orang lain. Jiwanya tertutup dipresentasikan oleh tokoh Adara.

“Apa itu?" tanya Pras penasaran.

“Aku nggak bisa cerita. Maafin aku, Mas.” (Malka, 2018: 203).

Tertutupnya Adara mengenai masa lalu yang membuatnya malu, sedih, kecewa, dan meratapi atas nasib menimpa dirinya.

Jiwa tertutup lainnya dipresentasikan oleh tokoh Pras kepada teman-temannya.

"Foto istri lo mana, Pras? Tanya Tino menyapu pandangannya ke sekeliling dinding kamar.

Pras diam tak menyahut. Ia tak tahu harus menjelaskan dari mana dulu.

"Lo nggak tidur sama istri lo?"

"Sok tau lo!" Pras menjawab singkat (Malka, 2018: 142).

Sikap diam Pras saat ditanya tentang foto istrinya yang tidak terpampang di kamarnya 
menunjukkan bahwa Pras tidak bisa menceritakan masalahnya kepada temannya.

(2)Kurang menarik perhatian orang lain

Kurang menarik merupakan ketidaktertarikan terhadap sesuatu yang baru dan tidak biasa dalam lingkungan sekitar, sehingga mendapat penolakan dari orang lain. Kurang menarik perhatian orang lain dipresentasikan oleh tokoh Adara terhadap penampilannya yang kurang menarik bagi masyarakat.

Ibu-ibu di samping Adara tersenyum mengejek. "Pasti uangnya dari ngebom turis," ujarnya lantang.

"Maksud ibu apa ya?" tanya Adara.

"Nah, situ kan teroris. Liat aja dandananya. Pasti teroris, Bu" hasudnya pada beberapa ibu di sebelahnya (Malka, 2018: 64).

Kurang menarik Adara terlihat saat masyarakat selalu mencibir, menghina, bahkan memfitnahnya. Hal itu menunjukkan bahwa Adara dengan penampilan syariat menimbulkan kurang menarik perhatian bagi masyarakat sekitar.

Kurang menarik lainnya dipresentasikan oleh tokoh Pras. Kurang menarik ini ditunjukkan melalui perlakuan Pras kepada relasi bisnisnya.

Tanpa menyahut ucapan Pras lagi, para calon relasi bisnisnya itu beranjak meninggalkan rumah Pras. Wajah mereka seketika berubah masam menahan jengkel akibat pengusiran yang dilakukan Pras (Malka, 2018: 323).

Kurang menarik Pras terlihat dari raut wajah relasi bisnis yang mendapat perlakuan darinya berubah menjadi masam dan tidak berminat lagi melanjutkan kerja sama mereka.

(3) Sukar bergaul

Sukar bergaul merupakan keadaan seseorang yang susah untuk menyesuaikan dengan orang lain. Sukar bergaul dipresentasikan oleh tokoh Adara dalam mengenal teman-teman suaminya, Pras.

"Wah, Pras. Ini istri lo? Kayaknya istri lo mesti nyobain minuman lezat ini deh. Ehm... siapa nama lo, cewek berdandan aneh? Ini gue ambilin khusus buat lo!” Gisha menyodorkan segelas kecil wine pada Adara.

Adara tersenyum lembut seraya mengambil gelas berisi minuman alkohol itu dan berjalan menuju tempat sampah. Lantas ia membuang isinya dan langsung menyerahkan gelas kosong itu pada Gisha. 
“Terima kasih,” ucapnya singkat pada Gisha (Malka, 2018: 215).

Sikap Adara yang sukar bergaul dengan teman perempuan Pras, yakni Gisha. Hal itu terlihat saat Adara membuang minuman alkohol di tempat sampah yang diberikan Gisha kepadanya. Sikap Adara yang membuang minuman tersebut menunjukkan adanya kesukaran dalam bergaul bersama Gisha.

Sukar bergaul lainnya juga dipresentasikan oleh tokoh Pras dalam menghadapi teman perempuan yang tergila-gila kepadanya.

"Gue udah ngomong sama lo, perempuan kadal! Gue nggak sudi lo ganggu hidup gue! Jangan pernah temuin gue lagi atau lo bakal gue bunuh! (Malka, 2018: 135).

Sikap Pras yang menolak teman perempuannya ditunjukkan dengan ucapan kasar yang keluar dari mulutnya.Hal itu menunjukkan adanya kesukaran bergaul dari Pras yang terlihat dari sikapnya dan perbedaan lingkungan hidup di antara keduanya.

2. Regresi

Regresi merupakan gerak mundur yang berfungsi sebagai sarana untuk penyesuaian individu terhadap dunia dalam atau batinnya sendiri. Regresi kepribadian tokoh dalam penelitian ini dipresentasikan oleh tokoh Pras.

Mas, Mas nggak apa-apa?” tanya Adara yang langsung menyambut Pras, suaminya. Pras tak menyahut. Dengan langkah gontai ia menuju kamar. Ia merebahkan tubuhnya di kasur. Matanya terpejam dalam gumaman, bibirnya tak henti memanggil nama Darasi gadis impiannya (Malka, 2018: 76).

Ingatan masa lalu mengenai perempuan mengakibatkan konflik batin bagi Pras. Di satu sisi ia masih mencintai perempuan itu, namun di sisi lain ia telah menikah dengan perempuan pilihan kedua orang tuanya yang tidak ia cintai.

Regresi kepribadian tokoh lainnya dipresentasikan oleh tokoh Adara saat ingatan masa lalunya timbul mempengaruhi kepribadiannya.

Dirinya masih belum percaya, kedua orangtuanya itu sudah terdiam dingin dan kaku. Dara seketika menjerit histeris.

"PAPA!! MAMA!! JANGAN TINGGALIN DARA!!"

"PAPA!! MAMA!! BANGUN!!" Dara mengguncang-guncangkan tubuh keduanya bergantian (Malka, 2018: 99). 
Ingatan masa lalu Adara mengenai kematian kedua orang tuanya menyebabkan konflik batin, akibat tidak terima menanggung hidup sendiri. Namun, ingatan masa lalu tersebut memberikan pelajaran berharga baginya untuk mendapatkan hidayah. Hal itu menimbulkan adanya perubahan dan penyesuaian yang baik dalam mengasah pribadi lebih mengenal dengan Allah taala.

\section{PEMBAHASAN}

\section{Dinamika Kepribadian Tokoh Ditinjau dari Segi Prinsip-prinsip Interaksi}

Para tokoh mengalami dinamika kepribadian baik dari segi prinsip-prinsip interaksi, kompensasi, dan penggabungan sesuai dengan psikologi Jung memandang bahwa dinamika kepribadian sebagai bentuk perubahan yang terjadi karena masalah kehidupan jiwa manusia kaitannya dengan pandangan agama (Alwisol, 2011: 62). Segi prinsip oposisi berisi konflik yang berinteraksi dengan tiga cara yakni saling bertentangan, saling mendukung, dan bergabung menjadi kesatuan. Saling bertentangan yang terjadi tokoh Pras dan kedua orang tuanya, karena Pras tidak mengikuti permintaan untuk menikah dengan perempuan pilihan tersebut. Pertentangan yang dilakukan Pras bertentangan dengan firman Allah taala untuk berbuat baik kepada kedua orang tua, yang terdapat di dalam Q.S Al-Isra ayat 23: “...dan janganlah engkau membentak keduanya, dan ucapkanlah kepada keduanya perkataan yang baik. "Selain itu, sikap Pras tersebut dipengaruhi oleh faktor pembentukan keluarga yang belum dipenuhinya. Faktor pembentukan keluarga dikemukakan oleh Ahmadi (2007: 225) yakni faktor objektif dan subjektif. Faktor objektif yakni adanya kesiapan berumah tangga dalam hal ekonomi,kedewasaan mental, dan sebagainya. Faktor subjektif yakni adanya dasar saling mencintai. Saling mendukung terlihat saat Pras menyetujui permintaan kedua orang tuanya. Sikap Pras yang setuju dengan pernikahan ini menunjukkan adanya kehendak untuk mengambil alih pemegang saham di perusahaan orang tuanya. Hal tersebut terjadi karena adanya faktor intern pembentuk akhlak yakni kemauan keras yang menggerakkan manusia bersungguh-sunguh mencapai sesuatu (Ya'qub dalam Firdaus, 2017: 73). Terlihat dari sikap 
Pras yang dengan gampangnya menerima permintaan untuk menikah, walaupun kedua faktor pembentukan keluarga belum dipenuhinya. Bergabung menjadi kesatuan terlihat ketika Pras mengucapkan ijab kabul sebagai wujud dari permintaan kedua orang tuanya untuk menikah. Permintaan kedua orang tuanya untuk menikahkan Pras dengan perempuan pilihan mereka sangat relevan dengan firman Allah taala yang terdapat dalam Q.S An-Nur ayat 32: "Dan nikahkanlah orang-orang yang masih membujang di antara kamu, dan juga orang-orang yang layak menikah, dan hamba sahaya yang laki-laki dan perempuan.” Interaksi dalam prinsip oposisi mempengaruhi pribadi Pras yang awalnya pembangkang menjadi pribadi yang patuh terhadap kedua orang tuanya.

Prinsip kompensasi mencegah agar kepribadian tidak menjadi gangguan saraf. Misalnya, ketika sikap sadar frustasi, maka sikap tak sadar mengambil alih (Alwisol, 2011: 50). Hal itu terlihat dari cobaan yang dialami Pras dan Adara membuat frustasi, sehingga berbagai sikap buruk akan terjadi di bawah ketidaksadaran. Sikap buruk tersebut seperti menzalimi diri sendiri, tidak bersyukur, berprasangka buruk, dan berputus asa dari rahmat Allah taala. Hal itu terdapat pada firman Allah taala mengenai larangan berputus asa dalam Q.S Az-Zumar ayat 53: "Katakanlah, wahai hamba-hamba-Ku yang melampaui batas terhadap diri mereka sendiri! Janganlah kamu berputus asa dari rahmat Allah."'Dengan demikian, cobaan yang menimpa tokoh Pras dan Adara menunjukkan bahwa keduanya memiliki kepribadian ammarah (nafsal-ammarah), yakni kepribadian yang cenderung pada tabiat dan mengejar prinsip-prinsip kenikmatan, serta ditentukan oleh syahwat (menginginkan birahi, kesukaan diri, ingin tahu, campur tangan orang lain, dan sebagainya) dan ghadah (tamak, berkelahi, keras kepala, sombong, angkuh, dan sebagainya) (Hasanah, 2015: 116-117). Kepribadian ammarah Pras terlihat dari sisi syahwat dan ghadah. Sisi syahwat yakni ingin tahunya yang berlebihan saat mencari perempuan dan istri yang ia cintai, sedangkan dari sisi ghadah terlihat dari sifat tamaknya menginginkan sesuatu, tanpa mempedulikan orang lain. Kepribadian Adara dari sisi ghadah yakni terlihat dari keras kepalanya dalam menerima ketetapan Allah taala.

Prinsip penggabungan menyatukan pertentangan-pertentangan yang ada dan dicapai 
melalui fungsi transenden (luar kesanggupan manusia) tentang ketuhanan (Alwisol, 2011: 50). Hal itu terlihat dari berbagai masalah yang dihadapi, namun Adara dan Pras selalu bersabar dan meyakini bahwa semua yang terjadi sudah menjadi ketetapan Allah taala. Hal itu relevan dengan firman Allah taala dalam Q.S Al-Muddassir ayat 7: "Dan karena Tuhanmu, bersabarlah. "Berdasarkan hal itu, sikap Adara dan Pras menunjukkan adanya kepribadian muthmainnah (nafsal-muthmainnah). Kepribadian muthmainnah merupakan kepribadian yang berorientasi pada komponen kalbu untuk mendapatkan kesucian, sehingga diri menjadi tenang dalam beribadah, mencintai, bertaubat, bertawakal, dan mencari rida Allah taala (Hasanah, 2015: 118). Kepribadian muthmainnah Adara terlihat dari ketenangannya dalam mencari rida Allah taala. Kepribadian muthmainnah Prasterlihat dari ketakwaannya mengikhlaskan segala ujian dari Allah taala.

\section{Dinamika Kepribadian Tokoh Ditinjau dari Segi Fungsi Penggunaan Energi Psikis}

Fungsi penggunaan energi psikis tampak dari adanya kekuatan semangat, keinginan, dan kemauan (Alwisol, 2011: 50). Kekuatan semangat dipengaruhi oleh adanya dorongan dari dalam maupun dari luar. Dorongan dari dalam berupa dorongan keberagamaan, cinta, kerja, sedangkan dari luar berupa dorongan nasihat dan keluarga. Dorongan keberagamaan terlihat dari keyakinan terhadap Allah taala dalam menjalani kehidupan yang penuh dengan cobaan. Hal itu relevan dengan firman Allah taala dalam Q.S Al-Baqarah ayat 45: "Dan mohonlah pertolongan kepada Allah dengan sabar dan salat. Dan salat itu sungguh berat, kecuali bagi orang-orang yang khusuk." Dorongan cinta terlihat dari segala ikhtiar yang dilakukan untuk tetap mempertahankan ikatan suci pernikahan. Hal itu relevan dengan firman Allah taala dalam Q.S An-Nisa' ayat 1: “...dan peliharalah hubungan kekeluargaan. "Dorongan kerja terlihat dari semangat untuk mempertahankan perusahaan yang terancam bangkrut. Dorongan nasihat dan keluarga terlihat dari dukungan doa yang selalu terpanjatkan dalam setiap ikhtiar yang dilakukan. Hal itu sesuai dengan firman Allah taala dalam Q.S An-Najm ayat 39: "Dan bahwa manusia hanya memperoleh apa yang telah diusahakannya." 
Kemauan dan keinginan merupakan dorongan yang mengarah pada satu tujuan. Kemauan melalui usaha yang nyata atau ikhtiar yang dilakukan, sedangkan keinginan merupakan dorongan berupa harapan dalam bentuk doa. Kemauan terlihat dari ikhtiar untuk mempertahankan rumah tangga. Hal itu dilakukan untuk mencapai tujuan, yakni memperbaiki kehidupan rumah tangga agar bahagia dan diridai Allah taala. Sikap tersebut relevan dengan Undang-Undang (UU) No. 1 tahun 1974 tentang Perkawinan Pasal (1) ikatan lahir batin antara seorang pria dan wanita sebagai suami istri dengan tujuan membentuk keluarga (rumah tangga) yang bahagia dan kekal berdasarkan Ketuhanan Yang Maha Esa (Wibisana, 2016: 192). Selain itu, kemauan didapatkan dengan usaha, namun tidak melupakan doa sebagai keinginan terhadap Allah taala. Keinginan terlihat dari setiap doa yang selalu dipanjatkan untuk keistikamahan memeluk agama Islam, keberkahan hidup yang diridai Allah taala, dan berharap kekuatan dalam menghadapi setiap masalah. Sikap tersebut relevan dengan firman Allah taala dalam Q.S Al-Baqarah ayat 152: "Maka ingatlah kepada$K u$, Aku pun akan ingat kepadamu. Bersyukurlah kepada-Ku, dan janganlah kamu ingkar kepada-Ku. 'Dengan demikian, doa yang dipanjatkan menunjukkan pribadi bersifat religius dalam menambah keimanan dan ketakwaan kepada Allah taala. Hal ini mengakibatkan dinamika kepribadian terhadap perkembangan pribadi yang lebih tawaduk atas perintah Allah taala untuk selalu menerima ketetapan-Nya yang telah ditetapkan.

\section{Dinamika Kepribadian Tokoh Ditinjau dari SegiTujuan Penggunaan Energi Psikis}

Dinamika kepribadian tokoh yang ditinjau dari segi tujuan penggunaan energi psikis dapat dilihat dari: (1) progresi: sikap ekstrovert (terbuka) dan sikap introvert (tertutup); (2) dan regresi (Alwisol, 2011: 53). Sikap ekstrovert (terbuka) lebih mengarahkan kepribadian ke luar dari pada ke dalam diri sendri. Seorang ekstrovert memiliki sifat sosial lebih banyak dari pada merenung dan berpikir, penuh dengan motif-motif yang dikoordinasi oleh kejadiankejadian eksternal (Jung dalam Rokhmansyah, 2018: 25-26). Sikap ekstrovert (terbuka) tokoh Adara dan Pras terlihat dari lancar dalam pergaulan, komunikasi sosialnya baik dan bersifat ramah tamah, berpembawaan riang gembira, optimis dan tidak putus asa dalam 
menghadapi konflik, serta bersikap tenang, dan memiliki keuletan dalam berpikir. Sikap tersebut menunjukkan adanya akhlak yang baik. Hal tersebut dipengaruhi oleh faktor lingkungan yang berpengaruh terhadap perbedaan kepribadian antara individu satu dengan lainnya (Schultz \& Schultz dalam Septiarini dan Renni, 2017: 80). Selain itu, sikap introvert (tertutup) tokoh Adara dan Pras lebih mengarah pada dalam dirinya sendiri, terutama saat mengalami tekanan batin, dan merasa bisa menyelesaikan suatu permasalahan tanpa bantuan dari orang lain (Jung dalam Rokhmansyah, 2018: 26). Sikap introvert (tertutup) terlihat dari jiwanya tertutup, kurang menarik perhatian orang lain, dan sukar bergaul. Sikap tertutup tokoh tersebut menunjukkan bahwa lebih selektif dan memandang subjektif terhadap suatu permasalahan (Jung dalam Rahmawati, 2018: 4). Selektif dalam hal memilih kejadian yang harus diceritakan kepada orang lain dan memandang subjektif bahwa permasalahannya mampu ia selesaikan sendiri tanpa harus menceritakannya kepada orang lain.

Regresi sebagai sarana untuk penyesuaian individu terhadap dunia dalam atau batinnya sendiri. Regresi kepribadian tampak dari aktifnya ketidaksadaran personal berupa kompleks yang berisi ingatan masa lalu (Alwisol, 2011: 53). Regresi terlihat dari ingatan masa lalu tokoh Adara dan Pras atas cobaan yang menimpa. Hal itu relevan dengan firman Allah taala dalam Q.S Al-Luqman ayat 17: “...dan bersabarlah terhadap apa yang menimpamu.” Berbagai masalah dan cobaan hidup harus dijalani, serta berusaha memperbaiki semuanya. Hal itu dipengaruhi oleh faktor lingkungan dan belajar yang mempengaruhi setiap fase kepribadian individu (Schultz dan Schultz dalam Septiarini dan Renni, 2017: 80). Dengan demikian, kepribadian yang awalnya buruk, mengalami dinamika lebih baik. Hal itu dipengaruhi oleh faktor-faktor pendukung dan adanya dorongan untuk mencapai tujuan hingga pada titik puncak kebahagiaan.

\section{SIMPULAN}

Dinamika kepribadian di dalam novel Harapan di Atas Sajadah karya Mawar Malka secara psikologi Jung menunjukkan bahwa tokoh mengalami dinamika didasari oleh masa lalu dan aspirasi masa depan sebagai pembentuk kepribadian yang berhubungan dengan 
persoalan sosial dan hubungannya dengan Sang Maha Pencipta. Dengan demikian, ketakwaan dan ikhtiar yang dilakukan dalam menghadapi ujian mempengaruhi pribadi tokoh menjadi lebih baik dan menjadikan dekat dengan Allah taala.

\section{DAFTAR RUJUKAN}

2 September 2018. hlm. 157-172.

Ahmadi, Abu. 2007. Psikologi Sosial. Jakarta: PT Rineka Cipta.

Alwisol. 2011. Psikologi Kepribadian. Malang: UMM Pres.

Departemen Agama RI. 2009. Al-Qur'an Terjemah \& Asbabunnuzul. Surakarta:

Firdaus. 2017. Membentuk Pribadi Berakhlakul Karimah secara Psikologis. Jurnal AlDzikra. Vol. XI No. 1. Januari-Juni 2017.

Hasanah, Muhimmatul. 2015. Dinamika Kepribadian menurut Psikologi Islami.

Hubbu Karya Mashuri Berdasarkan Perspektif Jung. Jurnal Pendidikan Humaniora. Vol. 1 No. 2 Juni 2013. hlm. 207-212.

Jung. Transformatika: Jurnal Bahasa, Sastra, dan Pengajarannya. Vol. 2 No.

Jurnal Ummul Qura. Vol. VI No. 2 September 2015.

Malka, Mawar. 2018. Harapan di Atas Sajadah. Jakarta: Wahyu Qolbu.

Negeri Para Bedebah Karya Tere Liye Kajian Psikoanalisis Carl Gustav

Pustaka Al Hanan.

Rahmawati, Dian Lufia. 2013. Dinamika Kepribadian Tokoh Utama dalam Novel

Rokhmansyah, Alfian. 2018. Struktur Kepribadian Tokoh dalam Novel The Sweet Sins Karya Rangga Wirianto Putra. Deiksis Jurnal Pendidikan Bahasa dan Sastra Indonesia. Vol. 5 No. 2.

Sembiring, Renni Handayani. dkk. 2018. Kepribadian Tokoh Utama dalam Novel

Septiarini, Tri dan Renni Handayani Sembiring. 2017. Kepribadian Tokoh dalam Novel Mencari Perempuan yang Hilang (Kajian Psikoanalisis Carl Gustav Jung). Jurnal Lingua. Vol. 12 No. 2. Desember 2017.

Wibisana, Wahyu. 2016. Pernikahan dalam Islam. Jurnal Pendidikan Agama Islam-Ta'lim. Vol. 14 No. 2. 